\title{
MARGHERITA BISCEGLIA, La materia arturiana nella lirica antico-francese. Alcuni esempi
}

\section{Martina Crosio}

\section{(2) OpenEdition}

\section{Journals}

Édition électronique

URL : https://journals.openedition.org/studifrancesi/43400

DOI : $10.4000 /$ studifrancesi.43400

ISSN : 2427-5856

Éditeur

Rosenberg \& Sellier

\section{Édition imprimée}

Date de publication : 1 juin 2021

Pagination : 188

ISSN : 0039-2944

\section{Référence électronique}

Martina Crosio, "MARGHERITA BISCEgLIA, La materia arturiana nella lirica antico-francese. Alcuni esempi 》,

Studi Francesi [En ligne], 193 (LXV | I) | 2021, mis en ligne le 01 juillet 2021, consulté le 15 octobre

2022. URL : http://journals.openedition.org/studifrancesi/43400 ; DOI : https://doi.org/10.4000/ studifrancesi. 43400

Ce document a été généré automatiquement le 15 octobre 2022

\section{(c) (i) (9)}

Creative Commons - Attribution - Pas d'Utilisation Commerciale - Pas de Modification 4.0 International - CC BY-NC-ND 4.0

https://creativecommons.org/licenses/by-nc-nd/4.0/ 


\title{
MARGHERITA BISCEGLIA, La materia arturiana nella lirica antico-francese. Alcuni esempi
}

\author{
Martina Crosio
}

\section{RÉFÉRENCE}

MARGHERITA BISCEGLIA, La materia arturiana nella lirica antico-francese. Alcuni esempi, "Carte Romanze" 7/2, 2019, pp. 219-247 (en ligne).

1 M.B. mène une enquête sur la pénétration de la matière de Bretagne dans la production lyrique des trouvères. Elle identifie trois types de renvois à la littérature arthurienne dans la poésie du Nord de la France: les expressions figées concernant des personnages exemplaires comme Tristan; les allusions plus précises qui témoignent d'une réception et d'une reprise plus approfondie de la littérature contemporaine; les motifs narratifs tirés d'une œuvre spécifique ou faisant partie d'un imaginaire littéraire commun tels que l'arc qui ne faut, l'esperansa bretona et le blanc cerf. De la série d'exemples cités se dégage clairement la refonctionnalisation constante des motifs arthuriens qui sont adaptés à la poétique auto-référentielle de la fin'amor. 